\title{
Effect of Bio and Inoroganic Fertilization on Growth and Yield of Some Sugar Cane Varieties
}

\author{
Abd El- Azez Y.M. ${ }^{1}$, B.A. Hassouua ${ }^{2}$ and S.H. Fathi ${ }^{2}$ \\ ${ }^{1}$ Sugar Crops. Ins., Agric. Res. Center, Giza, Egypt \\ ${ }^{2}$ Soils, Water and Environ. Res. Ins., Agric. Res. Center, Giza, Egypt \\ Received: 30 Oct. 2020 / Accepted 15 Dec. 2020 / Publication date: 30 Dec. 2020
}

\begin{abstract}
Field experiment was carried out at Mallawi Agriculture Research Station, Minia Governorate, (latitude of $28^{\circ} \mathrm{N}$, latitude of $30^{\circ} \mathrm{E}$ and latitude of $49 \mathrm{~m}$ above sea level ) Egypt, during the two successive seasons (2016/2017and 2017/2018). To study the effect of addition of bio fertilizer (Azotobacter chroccocum) and different levels of inorganic nitrogen fertilizer (Three rates of $\mathrm{N}$ fertilizer $100 \%, 75 \%$ and $50 \%$ of recommended dose RD) on stalk diameter, stalk length, stalk weight, total soluble solids purity, sucrose, sugar recovery sugar yield and cane yield of three sugar cane varieties (G.99-103, G.472003 and G.T.54-9) strip plot design with three reps. The results indicated that sugar cane varieties and bio fertilizer (Azotobacter chroccocum) with different levels of inorganic nitrogen fertilizer exhibit significant effects on all studied traits in both seasons. The variety G.99-103 recorded the highest values of stalk diameter, stalk length, stalk weight and $\mathrm{N} \%$, N uptake plant, $\mathrm{N}$ uptake fed. ${ }^{-1}$, millable cane ( ton fed $^{-1}$ ) and sugar yield (ton fed ${ }^{-1}$ ) in both seasons, while G.T.54-9 variety recorded the highest values of total soluble solids, purity $\%$, sucrose and sugar recovery $\%$. The addition $75 \% \mathrm{~N}\left(160 \mathrm{~kg} \mathrm{~N} \mathrm{fed}^{-1}\right)+$ Azotobacter chroccocum gave the highest values in all studied characters except purity \% in both seasons. The interactions between sugar cane varieties and bio fertilizer (Azotobacter chroccocum) with different levels of inorganic nitrogen fertilizer significantly affected on the studied traits in both seasons. Under the conditions of present work, the results suggest that planting G.99-103 variety with $160 \mathrm{~kg} \mathrm{~N}$ $\mathrm{fed}^{-1}+$ Azotobacter chroccocum is highly recommended to obtain the highest cane and sugar yields.
\end{abstract}

Keywords: Biofertilizer, Azotobacter, Cane yield, Sugarcane

\section{Introduction}

Sugar cane is the main sugar crop in Upper Egypt. About 90 percent of the yield is used for sugar extraction (Essaam et al., 2020). The role of sugar cane variety is considered the main factor in governing the expected sugar yield. It is well to known that, the commercial variety G.T.54-9 occupies most of sugar cane area in Egypt. Recently, Sugar Crops Research Institute produced some promising varieties of sugar cane among them G.2003-47 and G.99-103, many studies were designed to select among the produced varieties in yield and its components, as well as, juice quality parameters among them El-Shafai and Ismail (2006), Yousif et al. (2015), and Ahmed (2017). (Ibraheem, Abd Elateef 2016 and Ali, 2019). Zaki (2017) indicated that the examined sugarcane varieties differed significantly Promising varieties G.99-103 recorded the highest values of number of millable cane $\mathrm{m}^{-2}$, millable cane height, diameter and cane yield, while G.T. 54-9 surpassed the other varieties respect to brix, sucrose, sugar recovery percentages and sugar yield in plant cane.

Nitrogen is one of the most important nutrients to increase plant growth and yield and due to its role in chemical compounds such as proteins, nucleic acids and many other components, (Berger et al., 2013). The sustainable production of sugarcane could be recovered by practicing the inoculation of bio fertilizers particularly the Azotobacter bio fertilizer. Non symbiotic $\mathrm{N}_{2}$ fixing bio fertilizer which fix atmospheric $\mathrm{N}_{2}$ to its available forms as nitrate form besides $\mathrm{N}_{2}$ fixation Azotobacter synthesizes and secretes considerable amounts of biologically active substances like B vitamins, nicotinic acid, pantothenic acid, biotin, heteroxins and gibberelins etc, Azotobacter also produces traces of indole acetic acid, folic acid and gibberllin like substances sufficient to cause change in plant physiology, which enhance root growth of plants (Dada et al., 2020; Ambesh et al., 2017 and Wani, 2016). Bio fertilization has been used as an alternative to chemical fertilizers to increase soil fertility and crop production in sustainable agriculture (Das and Pradhas, 2016 and WU et al., 2005). This will be a useful

Corresponding Author: Abd El- Azez Y.M., Sugar Crops. Ins., Agric. Res. Center, Giza, Egypt.

E-mail: dr.yasserabdelazez@gmail.com 
shelter to solve problems of low soil fertility and crop productivity. Nitrogen bio fertilizers, especially Azotobacter have a greater potential for application in non-leguminous crop. The genus Azotobacter belongs to family Azotobacteriaceae_including gram negative, free-living asmybiotic nitrogen fixing (up to $10-20 \mathrm{~kg} \mathrm{~N} \mathrm{ha}^{-1}$ ) diazotroph (Kader et al., 2002). Azotobacter is the genus of great interest in agricultural application due to their free nitrogen fixing ability. Few studies have found out bio fertilizer use for sugar cane, in spite of the fact that a symbiotic nitrogen fixed by bacteria replaces $60 \%$ of the nitrogen needed cultivar (corresponding to $\mathrm{kg} \mathrm{N}$ ha-1) and its harvested in more than 90 countries worldwide (Araujo et al., 2020 and Serna-cock et al., 2011). Nemeat et al., (2015) Showed that juice parameters of sugar beet roots in terms of sucrose and Purity percentages significantly affected by application methods of bio fertilization. The foliar application recorded the positive and significant superiority for both of sucrose and purity percentages in both seasons. This observation may be due to foliar application of bio fertilization leads to direct improving in plant metabolism which reflected on storage materials in terms of sucrose consequently improving purity \%.The influence of bio fertilization on juice quality of sugar beet roots.

The objective of this investigation was studding the positive effects of inoculation of Azotobacter bio fertilizer and chemical nitrogen fertilizer on growth and yield parameters in sugarcane var. (G.T.549, G.47-2003 and G 99-103) under field conditions.

\section{Materials and Methods}

\section{Microbial strains:}

Isolates of $A$. chroococcum were isolated from rhizosphere soil of sugarcane plant collected from several locations of El-Minia Governorate. Twenty isolates of A. chroococcum was isolated at random from rhizosphere of different varieties of sugar cane at the different stages of Minia governorate. After purification, the isolates were tested towards their efficiency for nitrogen fixation by growing in Ashby's modified N-deficient broth (Abdel-Malek and Ishac, 1968) for Azotobacter isolates. The nitrogen fixing capability of the isolates was achieved using the ambient assay of nitrogenase activity according to (Postage 1972).

\section{Determination of bacteria:}

In vivo studies the experiment count of $A$. chroococcum and total count of bacteria was estimated at 50 days after cultivation in rhizosphere soils of sugarcane plants. To determine numbers of $A$. chroococcum dilution frequency method and (Haskin's 1934) were used to determination numbers of A. chroococcum also total count of bacteria as described by (Allen 1959). At 50, 75and 100 days after cultivation the bacterial population dynamics in the rhizosphere of the plants Furthermore, the nitrogenase enzyme activity in rhizosphere of plant was measured as acetylene reduction activity (ARA) by GC analysis according to (Somasegaran and Hoben, 1994). The most probable number MPN $\left(\times 10^{6}\right.$ cfu/g dry soil) was measured in specific Azotobacter species were Ashby's_medium the same periods in both seasons (Cochran, 1950).

\section{The field experiment:}

Field experiment was carried out at Mallawi Agricultural Research Station, Minia Governorate, Egypt in the two successive seasons of 2016/2017 and 2017/2018 on sugar cane plants to study the effect of $A$. chroococcum culture and nitrogen fertilization for three varieties (G.T.54-9, G.47-2003, G99-103) of sugarcane. The experiment was conducted in a clay loam soil in strip plot design with randomize complete blocks Design (RCBD) with three replicates. The vertical plots were occupied with three varieties, while the horizontal plots were devoted to the four levels of nitrogen fertilizer mixed with bio fertilizer using (Azotobacter chroococcum) culture.

\section{Treatments:}

1. G.T.54-9 2. G.47-2003 3. G.99-103.

Four levels of nitrogen fertilizer mixed with bio fertilizer using (Azotobacter chroococcum) culture.

1. Control $100 \% \mathrm{~N}\left(210 \mathrm{~kg} \mathrm{~N}^{-1} \mathrm{~d}^{-1}\right)$.

2. $50 \% \mathrm{~N}\left(105 \mathrm{~kg} \mathrm{~N} \mathrm{fed}^{-1}\right)+$ Azotobacter chroococcum .

3. $75 \% \mathrm{~N}\left(160 \mathrm{~kg} \mathrm{~N} \mathrm{fed}^{-1}\right)+$ Azotobacter chroococcum . 


\section{4. $100 \% \mathrm{~N}\left(210 \mathrm{~kg} \mathrm{~N} \mathrm{fed}^{-1}\right)+$ Azotobacter chroococcum .}

Each plot comprised 4 rows with seven meters in length and one meter in width, the plot area was $28 \mathrm{~m}^{2}\left(1 / 150 \mathrm{fed}^{-1}\right)$ the dry method of sugar cane planting was used. Sugar cane varieties were planted in spring season on the middle of March in both seasons. Nitrogen fertilizer was added as urea $(46 \%$ $\mathrm{N})$ at the rate of $210 \mathrm{~kg}$ nitrogen $\mathrm{fed}^{-1}$ recommended nitrogen (RD). Nitrogen fertilizer was split into two equal doses which were added after 60 days from planting and 30 days later. Phosphorus and potassium fertilizer were added at the rate of $60 \mathrm{~kg} \mathrm{P}_{2} \mathrm{O}_{5}$ and $50 \mathrm{~kg} \mathrm{~K}_{2} \mathrm{O}$ fed ${ }^{-1}$ in the form of calcium super phosphate $\left(15 \% \mathrm{P}_{2} \mathrm{O} 5\right)$ and potassium sulphate $\left(48 \% \mathrm{~K}_{2} \mathrm{O}\right)$ respectively. Phosphorus was added during land preparation, while potassium was applied after two months after planting. bio fertilizer $(A$. chroococcum) was added twice. The first inoculated by dipping the stalk-cutting in cell suspension of A. chroococcum $\left(1 \times 10^{6} \mathrm{cell} \mathrm{ml}^{-1}\right)$ for $60 \mathrm{~min}$ before planting and the second inoculated after 30 days from planting and directly irrigation was done. Some physical and chemical properties of the experimental soil is shown in Table 1.

Table 1: Some physical and chemical properties of the experimental soil

\begin{tabular}{|c|c|}
\hline \multirow{2}{*}{\multicolumn{2}{|c|}{$\begin{array}{r}\text { Property } \\
\text { Particle size distribution }(\%)\end{array}$}} \\
\hline & \\
\hline Sand & 10.20 \\
\hline Silt & 29.95 \\
\hline Clay & 59.85 \\
\hline Texture grade & Clay loam \\
\hline $\mathrm{CaCO}_{3}$ & 0.90 \\
\hline Saturation percent (S.P \%) & 41.00 \\
\hline $\mathrm{pH}$ (soil paste) & 8.12 \\
\hline \multirow{2}{*}{\multicolumn{2}{|c|}{$\begin{array}{l}\mathrm{E} . \mathrm{C}\left(\mathrm{dS} \mathrm{m} \mathrm{d}^{-1} \text {, at } 25^{\circ} \mathrm{C}\right) \\
\text { Soluble cations and anions }\left(\mathrm{meq}^{-1}\right) \text { : }\end{array}$}} \\
\hline & \\
\hline $\mathrm{Ca}^{++}$ & 1.60 \\
\hline $\mathrm{Mg}^{++}$ & 2.30 \\
\hline $\mathrm{Na}^{+}$ & 1.50 \\
\hline $\mathrm{K}^{+}$ & 0.24 \\
\hline $\mathrm{CO}_{3}{ }_{3}$ & 0.00 \\
\hline $\mathrm{HCO}_{3}^{-}$ & 2.88 \\
\hline $\mathrm{Cl}^{-}$ & 2.12 \\
\hline $\mathrm{SO}_{4}^{=}$ & 0.64 \\
\hline Total soluble- $\mathrm{N} \quad\left(\mathrm{mg} \mathrm{kg}^{-1}\right)$ & 25.40 \\
\hline Available- $\mathrm{P} \quad\left(\mathrm{mg} \mathrm{kg}^{-1}\right)$ & 13.80 \\
\hline Available-K $\quad\left(\mathrm{mg} \mathrm{kg}^{-1}\right)$ & 315.20 \\
\hline
\end{tabular}

\section{Data recorded:}

At harvest, twenty plants from the two middle guarded ridges of each treatment were taken at random to determine the following data:

-Stalk height $(\mathrm{cm})$ was measured from soil surface to the top point of visible dewlap.

-Stalk diameter $(\mathrm{cm})$ was measured at the middle part of stalk.

-Stalk weight $(\mathrm{kg})$.

Total soluble solids (TSS \%): It was determined using "Brix hydrometer" according to (A.O.A.C. 1995).

-Sucrose percentage was determined using saccharometer according to A.O.A.C. (1995).

-Purity percentage: It was calculated using the following formula according to Satisha et al., (1996). Juice Purity $\%=($ Sucrose $\% \div$ TSS $\%) \times 100$.

-Sugar recovery percentage (\%): It was calculated according to the following formula described by Yadav and Sharma (1980).

Sugar recovery $(\%)=[$ Sucrose $\%-0.4($ Brix $\%$ - Sucrose $\%)] \times 0.37$.

-Cane yield (ton $\mathrm{fed}^{-1}$ ): the mill able canes of two guarded rows of all plots were harvested, topped, cleaned, weighed and cane yield ton $\mathrm{fed}^{-1}$ was determined. 
-Sugar yield ton $\mathrm{fed}^{-1}$ : It was estimated according to the following equation:

Sugar yield ton $\mathrm{fed}^{-1}=$ Cane yield $\left(\right.$ ton $\left.\mathrm{fed}^{-1}\right) \times$ Sugar recovery $(\%)$.

\section{Nitrogen and nitrogen uptake analysis:}

Concentration of $\mathrm{N}$ and $\mathrm{N}$ uptake were analyzed from matured stalks. Five clean sample stalks from each plot were collected randomly. The finely ground and dried tissues were wet digested using sulphuric-perchloric acid mixture (1:1) as described by A.O.A.C (2000). Total nitrogen percentage was determined by Kjeldahl method according to Jackson (1967).

\section{Statistical analysis:}

Collected data were subjected to analysis of variance (ANOVA) in each season was performed. The measured variables were analyzed using MSTATC. Differences among treatments were evaluated by LSD test at 5\% according to procedure out lined by (Elias and Karim 1984 and Gomez and Gomez 1984).

\section{Results and Discussion}

The results in (Table 2) represent the nitrogenase activity of 20 Azotobacter isolates. It is clear that the best isolated with the highest recorded values was the isolate (Azt. 1) with sugar cane which attained (39.79 and $40.65 \mathrm{n}$ moles $/ \mathrm{C}_{2} \mathrm{H}_{4} / 1 \mathrm{ml}$ culture/ $\mathrm{hr}$.) in the first and second season, respectively.

Table 2: Nitrogenase activity of $A$. chroococcum isolates

\begin{tabular}{|c|c|c|}
\hline \multicolumn{3}{|c|}{ Nitrogenase activity n moles $/ \mathrm{C}_{2} \mathrm{H}_{4} / 1 \mathrm{ml}$ culture $/ \mathrm{hr}$ of } \\
\hline \multirow{2}{*}{ No. } & First season & Second season \\
\hline & $\mathrm{N}_{2}$-ase & $\mathrm{N}_{2}$-ase \\
\hline A. chroococcum 1 & 39.79 & 40.65 \\
\hline A. chroococcum 2 & 19.70 & 20.5 \\
\hline A. chroococcum 3 & 14.82 & 16.0 \\
\hline A. chroococcum 4 & 12.69 & 13.45 \\
\hline A. chroococcum 5 & 12.67 & 23.88 \\
\hline A. chroococcum 6 & 20.4 & 22.0 \\
\hline A. chroococcum 7 & 22.01 & 23.89 \\
\hline A. chroococcum 8 & 11.69 & 12.89 \\
\hline A. chroococcum 9 & 33.03 & 35.0 \\
\hline A. chroococcum 10 & 8.12 & 9.44 \\
\hline A. chroococcum 11 & 15.65 & 16.42 \\
\hline A. chroococcum 12 & 22.63 & 23.98 \\
\hline A. chroococcum 13 & 10.32 & 11.65 \\
\hline A. chroococcum 14 & 13.84 & 14.5 \\
\hline A. chroococcum 15 & 17.14 & 18.21 \\
\hline A. chroococcum 16 & 22.87 & 23.2 \\
\hline A. chroococcum 17 & 13.69 & 14.3 \\
\hline A. chroococcum 18 & 34.89 & 35.4 \\
\hline A. chroococcum 19 & 26.87 & 27.98 \\
\hline A. chroococcum 20 & 16.64 & 18.0 \\
\hline
\end{tabular}

The results in (Table 3) clearly indicated that counts of Azotobacter were much higher in rhizosphere samples soil of any of the tested varieties of sugar cane. The results also showed that the count of Azotobacter affected with the age of sugar cane varieties tested that decreased at the late stages at the ages of 100 days after planting. The highest numbers were found in samples of rhizosphere of all variety G.T.54-9, G.47-2003 and G99-103 with $75 \% \mathrm{~N}\left(160 \mathrm{~kg} \mathrm{~N}\right.$ fed $\left.^{-1}\right)+$ A. chroococcum (20.4 and 
21.0), (20.9 and 20.8) and $\left(21.6\right.$ and $\left.21.9 \times 10^{4}\right)$ in the first and second season at 75 days after planting, respectively.

The results in (Table 4) indicated that the total counts of bacteria were higher in rhizosphere samples soil of all plants of sugar cane varieties under study. It was shown that after three different stages of plant growth ranged from 50 to 100 days after sowing, the total count of bacteria increased at the ages started from 50 to 75 days after sowing, while decreased in all varieties of sugar cane plants at 100 days. The highest numbers were observed in samples of rhizosphere variety G.T.54-9, G.47-2003 and G99-103 75\% N (160 kg N fed $\left.{ }^{-1}\right)+A$. chroococcum by (15.3 and 15.6), (15.1 and 15.7) and (15.2 and $15.5 \times 10^{6}$ ) in the two growing seasons at age of 75 days after planting, respectively.

Table 3: Numbers of Azotobacter $\times 10^{4}$ (M.P.N. $/ g$ ) in the rhizosphere of different varieties of sugar cane plant

\begin{tabular}{lcccccc}
\hline & \multicolumn{3}{c}{ First season } & \multicolumn{3}{c}{ Second season } \\
\cline { 2 - 7 } Treatments & $\begin{array}{c}\mathbf{5 0} \\
\text { days }\end{array}$ & $\begin{array}{c}\mathbf{7 5} \\
\text { days }\end{array}$ & $\begin{array}{c}\mathbf{1 0 0} \\
\text { days }\end{array}$ & $\begin{array}{c}\mathbf{5 0} \\
\text { days }\end{array}$ & $\begin{array}{c}\mathbf{7 5} \\
\text { days }\end{array}$ & $\begin{array}{c}\mathbf{1 0 0} \\
\text { days }\end{array}$ \\
\hline G.T.54-9 100\% N RD & 4.3 & 5.3 & 3.6 & 4.5 & 5.5 & 3.8 \\
G.T.54-9 50 \% N RD + A. chroococcum & 12.7 & 16.7 & 9.7 & 13 & 16.8 & 10.1 \\
G.T.54-9 75 \% N RD + A. chroococcum & 14.4 & 20.4 & 11.4 & 14.5 & 21 & 11.9 \\
G.T.54-9 100 \% N RD + A. chroococcum & 5.3 & 6.3 & 9.0 & 5.5 & 6.5 & 9.3 \\
G.47-2003 100\% N RD & 4.4 & 5.4 & 3.3 & 4.7 & 5.7 & 3.6 \\
G.47-2003 50 \% N RD + A. chroococcum & 14.4 & 18.4 & 9.2 & 14.8 & 18.6 & 9.8 \\
G.47-2003 75 \% N RD + A. chroococcum & 15.4 & 20.9 & 11.3 & 15.7 & 20.8 & 11.7 \\
G.47-2003 100 \% N RD + A. chroococcum & 7.1 & 8.1 & 10.5 & 7.5 & 8.5 & 10.9 \\
G99-103 100\% N RD & 6.3 & 7.3 & 3.8 & 6.8 & 7.7 & 4.2 \\
G99-103 50 \% N RD + A. chroococcum & 13.6 & 18.6 & 10.8 & 13.9 & 18.9 & 11.4 \\
G99-103 75 \% N RD + A. chroococcum & 14.6 & 21.6 & 11.5 & 14.9 & 21.9 & 11.9 \\
G99-103 100 \% N RD + A. chroococcum & 9.2 & 10.1 & 9.1 & 9.7 & 10.5 & 9.5 \\
\hline
\end{tabular}

Table 4: Total count of bacteria $\times 10^{6}(\mathrm{CFU}) / \mathrm{g}$ dry soil in the rhizosphere of different varieties of sugar cane plants

\begin{tabular}{|c|c|c|c|c|c|c|}
\hline \multirow[b]{2}{*}{ Treatments } & \multicolumn{3}{|c|}{ First season } & \multicolumn{3}{|c|}{ Second season } \\
\hline & $\begin{array}{c}50 \\
\text { days }\end{array}$ & $\begin{array}{c}75 \\
\text { days }\end{array}$ & $\begin{array}{c}100 \\
\text { days }\end{array}$ & $\begin{array}{c}50 \\
\text { days }\end{array}$ & $\begin{array}{c}75 \\
\text { days }\end{array}$ & $\begin{array}{r}100 \\
\text { days }\end{array}$ \\
\hline G.T.54-9 100\% N RD & 5.0 & 5.7 & 4.7 & 5.3 & 5.9 & 5.1 \\
\hline G.T.54-9 $50 \%$ N RD + A. chroococcum & 11.0 & 13.0 & 10.7 & 11.4 & 13.3 & 10.9 \\
\hline G.T.54-9 $75 \%$ N RD + A. chroococcum & 13.3 & 15.3 & 12.3 & 13.5 & 15.6 & 12.6 \\
\hline G.T.54-9 $100 \%$ N RD + A. chroococcum & 11.6 & 12.6 & 11.0 & 11.9 & 12.8 & 11.3 \\
\hline G.47-2003 100\% N RD & 5.1 & 5.9 & 4.9 & 5.4 & 6.2 & 5.1 \\
\hline G.47-2003 $50 \% \mathrm{~N} \mathrm{RD}+A$. chroococcum & 11.8 & 12.8 & 10.9 & 12.1 & 13 & 11.2 \\
\hline G.47-2003 $75 \%$ N RD + A. chroococcum & 13.1 & 15.1 & 13.1 & 13.4 & 15.7 & 13.4 \\
\hline G.47-2003 $100 \% \mathrm{~N}$ RD + A. chroococcum & 11.9 & 12.9 & 11.8 & 12.2 & 13.1 & 12 \\
\hline G99-103 100\% N RD & 5.2 & 5.5 & 4.5 & 5.6 & 6.0 & 4.7 \\
\hline G99-103 $50 \% \mathrm{~N}$ RD + A. chroococcum & 12. 1 & 13.0 & 10.5 & 12.4 & 13.4 & 10.7 \\
\hline G99-10375\% N RD + A. chroococcum & 13.8 & 15.2 & 13.2 & 14.0 & 15.5 & 13.4 \\
\hline G99-103 $100 \%$ N RD + A. chroococcum & 12.5 & 13.5 & 11.1 & 12.9 & 14.0 & 11.4 \\
\hline
\end{tabular}

\section{Stalk length, diameter and weight of sugar cane plant:}

\subsection{Varietal effect:}

Data in Table (5) showed that sugar cane varieties differed significantly in the three traits in both seasons. G99-103 surpassed the other two varieties G.T.54-9 and G.47-2003 by 14.62 and $16.44 \%$ in stalk length, 23.94 and $25.63 \%$ in stalk diameter and 15.71 and $28.57 \%$ in stalk weight in the $1^{\text {st }}$ season, 
respectively. The same trend in $2^{\text {nd }}$ season was recorded for these varieties. These results may be attributed to the gene make up. This result is in agreement with those obtained by Yasser (2008), Yousif et al., (2015), Zaki, (2017) and Abu- Ellail et al., (2018).

1.2. Bio and inorganic fertilizer effect on stalk length, diameter and weight of sugar cane plant:

Results in Table (5) revealed that these treatments affected significantly the previous traits in both seasons. The results showed that the previous traits were increased by increasing mixing bio fertilizer with $50 \% \mathrm{~N}$ level to $75 \% \mathrm{~N}$ level then values of these traits of sugar cane plants decreased in both seasons with increasing mixing bio fertilizer with $100 \% \mathrm{~N}$ level. These findings are in accordance with those obtained by Chandrasekar et al., (2005) who revealed that application of chemical nitrogen with nitrogen fixing bacteria at all levels resulted increase in growth, yield the control (without bio fertilizers). These results are in agreement with those obtained by (Hari and Srinivasan 2005) and (Shankaraiah and Kalyanamurthy 2005).

Table 5: Effect of bio and inorganic fertilizer on stalk length, diameter and weight of some sugarcane varieties and their interactions in 2016/2017 and 2017/2018 seasons

\begin{tabular}{|c|c|c|c|c|c|c|c|c|}
\hline \multirow{4}{*}{ Bio and inorganic fertilizer } & \multicolumn{8}{|c|}{ Stalk length $(\mathrm{cm})$} \\
\hline & \multicolumn{4}{|c|}{ First season } & \multicolumn{4}{|c|}{ Second season } \\
\hline & \multicolumn{8}{|c|}{ Varieties } \\
\hline & $\begin{array}{c}\text { G.T.54- } \\
9\end{array}$ & $\begin{array}{l}\text { G.47- } \\
2003\end{array}$ & $\begin{array}{c}\text { G99- } \\
103\end{array}$ & Mean & $\begin{array}{c}\text { G.T.54- } \\
9\end{array}$ & $\begin{array}{l}\text { G.47- } \\
2003\end{array}$ & $\begin{array}{c}\text { G99- } \\
103\end{array}$ & Mean \\
\hline $100 \%$ N RD & 254.33 & 226.00 & 278.67 & 253.00 & 264.00 & 233.67 & 285.33 & 261.00 \\
\hline $50 \%$ N RD+A. chroococcum & 248.00 & 218.67 & 274.33 & 247.00 & 254.00 & 222.33 & 280.33 & 252.22 \\
\hline $75 \%$ N RD+A. chroococcum & 246.67 & 299.64 & 308.33 & 284.89 & 256.67 & 306.00 & 313.67 & 292.11 \\
\hline $100 \%$ N RD + A. chroococcum & 248.00 & 231.33 & 306.33 & 261.89 & 258.00 & 235.00 & 311.00 & 268.00 \\
\hline Mean & 249.25 & 243.92 & 291.92 & 261.69 & 258.17 & 249.25 & 297.58 & 268.33 \\
\hline LSD $_{0.05}$ & \multicolumn{4}{|c|}{19.20} & \multicolumn{4}{|c|}{19.24} \\
\hline LSD $_{0.05}$ & \multicolumn{4}{|c|}{21.08} & \multicolumn{4}{|c|}{18.76} \\
\hline LSD 0.05 & \multicolumn{4}{|c|}{28.22} & \multicolumn{4}{|c|}{30.10} \\
\hline \multicolumn{9}{|c|}{ Stalk Diameter $(\mathrm{cm})$} \\
\hline $100 \%$ N RD & 2.81 & 2.64 & 3.56 & 3.00 & 2.87 & 2.69 & 3.60 & 3.05 \\
\hline $50 \% \mathrm{~N}$ RD+A. chroococcum & 2.51 & 2.57 & 3.45 & 2.85 & 2.56 & 2.60 & 3.48 & 2.88 \\
\hline $75 \%$ N RD+A. chroococcum & 2.76 & 2.63 & 3.62 & 3.00 & 2.81 & 2.67 & 3.63 & 3.06 \\
\hline $100 \%$ N RD + A. chroococcum & 2.72 & 2.71 & 3.58 & 3.02 & 2.76 & 2.75 & 3.65 & 3.04 \\
\hline Mean & 2.70 & 2.64 & 3.55 & 2.97 & 2.75 & 2.68 & 3.59 & 3.01 \\
\hline LSD $_{0.05}$ & \multicolumn{4}{|c|}{0.04} & \multicolumn{4}{|c|}{0.03} \\
\hline LSD 0.05 & \multicolumn{4}{|c|}{0.04} & \multicolumn{4}{|c|}{0.05} \\
\hline LSD $_{0.05}$ & \multicolumn{4}{|c|}{0.01} & \multicolumn{4}{|c|}{0.02} \\
\hline \multicolumn{9}{|c|}{ Stalk weight (kg) } \\
\hline $100 \%$ N RD & 1.17 & 1.00 & 1.44 & 1.20 & 1.19 & 1.03 & 1.49 & 1.24 \\
\hline $50 \%$ N RD+A. chroococcum & 1.01 & 0.89 & 1.17 & 1.03 & 1.03 & 0.92 & 1.20 & 1.05 \\
\hline $75 \%$ N RD+A. chroococcum & 1.34 & 1.11 & 1.55 & 1.33 & 1.37 & 1.15 & 1.60 & 1.37 \\
\hline $100 \%$ N RD + A. chroococcum & 1.18 & 1.02 & 1.43 & 1.21 & 1.20 & 1.03 & 1.47 & 1.23 \\
\hline Mean & 1.18 & 1.00 & 1.40 & 1.19 & 1.20 & 1.03 & 1.44 & 1.22 \\
\hline LSD $_{0.05}$ & \multicolumn{4}{|c|}{0.14} & \multicolumn{4}{|c|}{0.15} \\
\hline LSD $_{0.05}$ & \multicolumn{4}{|c|}{0.09} & \multicolumn{4}{|c|}{0.11} \\
\hline LSD $_{0.05}$ & \multicolumn{4}{|c|}{ NS } & \multicolumn{4}{|c|}{ NS } \\
\hline
\end{tabular}

\subsection{Interactions effect:}

Effect of Interaction between varieties and treatments of $\mathrm{N}$ level mixed with bio fertilizer of $A$. chroococcum had significant effects on the previous traits. Fertilizing the tested verities with $75 \% \mathrm{~N}$ 
with bio fertilizer surpassed the other treatments in both seasons. Also, it was noticed that applying $100 \% \mathrm{~N}$ RD alone recorded higher values of these traits in both seasons over that of $50 \% \mathrm{~N}+$ bio fertilizer. These results may be attributed that Nitrogen element has a positive and active role in growth traits (length, diameter and weight) of sugar cane plants besides increasing the photosynthesis produced by solar energy conversion. These results coincide with that obtained by (Satwant 2012). Many studies illustrated that inoculation with only one beneficial microorganism generally increases plant growth and decreases pathogenic agent (Raimam et al., 2007).

\section{Sucrose\%, total soluble solids and purity percentages:}

\subsection{Varietal effect:}

Results in Table (6) showed that varieties of sugarcane differed significantly in total soluble solids , sucrose and purity\% traits in both seasons. Variety G.T.54-9 surpassed in sucrose, by 10.58 and 8.40 $\%$ over G.47-2003 and G99-103 in the $1^{\text {st }}$ season, respectively and 8.30 and $10.55 \%$ in the second season. Also, this superior was recorded for purity percentage where it was 8.46 and $2.84 \%$ over the G.47-2003 and G99-103 in the $1^{\text {st }}$ season, respectively and 8.06 and $0.83 \%$ in the $2^{\text {nd }}$ season, respectively. Regarding to total soluble solids \%, G.T.54-9 and G.47-2003 varieties surpassed G99-103 variety in both seasons but the difference between two varieties did not reach the level of significance. This result in quality may be due to the gene make up for varieties. Those findings coincide with that obtained by Yasser. (2008) and Abu-ellail et al., (2020).

\subsection{Bio and inorganic fertilizer Effect:}

Results presented in Table (6) revealed that bio and inorganic fertilizer significantly affected quality traits in both seasons. Treatment (3) recorded the highest values of total soluble solids and sucrose \% in both seasons followed treatment (2) then treatment (1) while treatment (4) recorded the lowest value of total soluble solids and sucrose in both seasons. It is noticed that the difference between treatments (2) and (3) did not reach level of significance in both seasons. This result may be attributed the active role of bio and inorganic fertilizer the increase of fertilization led to inverse effect on quality traits concerning purity $\%$, it was noticed that treatment (4) recorded the highest values of purity\% compared to the other treatments in both seasons. This result did not reach the level of significance between bio fertilizer with 50,75\% of Nitrogen fertilizer this result is in agreement with those obtained by Ishwaq Peerzada et al., (2009) Azotobacter is the genus of great interest in agricultural application due to their free nitrogen fixing ability. Here, emphasis is given on the role of polysaccharide in sustainable agriculture stalk and also to the survival in its own environments. Substances like amino acid produced by Azotobacter are involved in many processes that explain plant-grown promotion. Biochemical analysis of chlorophyll, nitrogen, phosphorous, potassium and protein content was higher in Azotobacter inoculated plants as compared to un inoculated control plants (Kravchenko et al., 2002).

\subsection{Interactions effect:}

Results in Table (6) showed that under bio fertilizer with 50 or $75 \%$ of $\mathrm{N}$ fertilizer level, all varieties recorded the highest values of quality traits in both season. Generally, G.T.54-9 variety surpassed the other two varieties G.47-2003 and G99-103 in quality traits (total soluble solids, sucrose and purity \%) when it was fertilized by bio fertilizer with $75 \%$ of $\mathrm{N}$ inorganic fertilizer in both season except total soluble solids $\%$ in the $1^{\text {st }}$ seasons, where the interaction between varieties and treatments was insignificant. These results are in agreement with that obtained by Nemeat et al., (2015), This observation may be due to foliar application of PGPR lead to direct improvement in plant metabolism which reflected on storage materials in terms of sucrose consequently improving purity $\%$. The influence of yeast on juice quality of sugar beet roots. The highest yield of the yield has been reported in treatment Azotobacter N100\% RD which significant than the other additional plant growth promoting benefits apart from the diazotrophic action of the Azotobacter inoculation in sugarcane. Similar results have been quoted by application of bio fertilizers (Azotobacter and Azospirillum) along with 100\% urea treatment highest yields of millet, (Echinochloa frumentacea (Roxb.) were obtained compared to control (Chandrasekar et al., 2005). 
Table 6: Effect of bio and inorganic fertilizer on total soluble solids, sucrose and purity $\%$ of some sugarcane varieties and their interactions in 2016/2017 and 2017/2018 seasons

\begin{tabular}{|c|c|c|c|c|c|c|c|c|}
\hline \multirow{4}{*}{ Bio and inorganic fertilizer } & \multicolumn{8}{|c|}{ Total Soluble Solids } \\
\hline & \multicolumn{4}{|c|}{ First season } & \multicolumn{4}{|c|}{ Second season } \\
\hline & \multicolumn{8}{|c|}{ Varieties } \\
\hline & $\begin{array}{c}\text { G.T.54- } \\
9 \\
\end{array}$ & $\begin{array}{l}\text { G.47- } \\
2003 \\
\end{array}$ & $\begin{array}{c}\text { G99- } \\
103 \\
\end{array}$ & Mean & $\begin{array}{c}\text { G.T.54- } \\
9 \\
\end{array}$ & $\begin{array}{l}\text { G.47- } \\
2003 \\
\end{array}$ & $\begin{array}{c}\text { G99- } \\
103 \\
\end{array}$ & Mean \\
\hline $100 \%$ N RD & 20.43 & 21.00 & 18.97 & 20.13 & 21.73 & 21.07 & 19.43 & 20.74 \\
\hline $50 \%$ N RD + A. chroococcum & 20.43 & 20.87 & 19.20 & 20.17 & 21.77 & 21.27 & 19.70 & 20.91 \\
\hline $75 \%$ N RD + A. chroococcum & 20.77 & 20.83 & 19.27 & 20.29 & 21.73 & 21.77 & 19.73 & 21.08 \\
\hline $100 \%$ N RD + A. chroococcum & 20.20 & 19.13 & 18.90 & 19.08 & 19.83 & 20.73 & 19.27 & 19.94 \\
\hline Mean & 20.47 & 20.46 & 19.08 & 20.00 & 21.27 & 21.21 & 19.53 & 20.67 \\
\hline LSD $_{0.05}$ & \multicolumn{4}{|c|}{0.15} & \multicolumn{4}{|c|}{0.14} \\
\hline LSD $_{0.05}$ & \multicolumn{4}{|c|}{0.15} & \multicolumn{4}{|c|}{0.12} \\
\hline LSD 0.05 & \multicolumn{4}{|c|}{0.25} & \multicolumn{4}{|c|}{0.25} \\
\hline \multicolumn{9}{|c|}{ Sucrose \% } \\
\hline $100 \%$ N RD & 17.10 & 16.07 & 15.67 & 16.28 & 17.50 & 16.37 & 16.07 & 16.64 \\
\hline $50 \%$ N RD + A. chroococcum & 17.57 & 15.97 & 15.73 & 16.42 & 17.87 & 16.27 & 16.10 & 16.74 \\
\hline $75 \%$ N RD + A. chroococcum & 17.77 & 16.07 & 15.83 & 16.56 & 18.17 & 16.37 & 16.13 & 16.89 \\
\hline $100 \%$ N RD + A. chroococcum & 17.13 & 15.60 & 14.97 & 15.90 & 17.33 & 16.00 & 15.10 & 16.14 \\
\hline Mean & 17.39 & 15.93 & 15.55 & 16.29 & 17.72 & 16.25 & 15.85 & 16.61 \\
\hline LSD $_{0.05}$ & \multicolumn{4}{|c|}{0.19} & & \multicolumn{2}{|c|}{0.18} & \\
\hline LSD $_{0.05}$ & \multicolumn{4}{|c|}{0.14} & & \multicolumn{2}{|c|}{0.15} & \\
\hline LSD $_{0.05}$ & \multicolumn{4}{|c|}{0.30} & & \multicolumn{2}{|c|}{0.32} & \\
\hline \multicolumn{9}{|c|}{ Juice purity\% } \\
\hline $100 \%$ N RD & 82.84 & 75.24 & 82.61 & 80.23 & 82.92 & 75.31 & 82.71 & 80.31 \\
\hline $50 \%$ N RD + A. chroococcum & 83.95 & 74.32 & 81.65 & 79.97 & 83.47 & 74.40 & 81.73 & 80.04 \\
\hline $75 \%$ N RD + A. chroococcum & 83.37 & 75.23 & 81.66 & 80.09 & 84.10 & 75.31 & 81.76 & 80.94 \\
\hline $100 \%$ N RD $+A$. chroococcum & 83.53 & 80.73 & 78.27 & 80.84 & 83.61 & 80.82 & 78.38 & 80.18 \\
\hline Mean & 83.42 & 76.38 & 81.05 & 80.28 & 83.08 & 76.39 & 82.39 & 80.37 \\
\hline LSD $_{0.05}$ & \multicolumn{4}{|c|}{1.07} & \multicolumn{4}{|c|}{1.08} \\
\hline LSD $_{0.05}$ & \multicolumn{4}{|c|}{0.67} & \multicolumn{4}{|c|}{0.66} \\
\hline LSD $_{0.05}$ & \multicolumn{4}{|c|}{1.76} & \multicolumn{4}{|c|}{1.73} \\
\hline
\end{tabular}

\section{Nitrogen $\%, N$ uptake plant ${ }^{-1}$ and $N$ uptake fed ${ }^{-1}$}

\subsection{Varietal effect:}

Results in Table (7) indicated that the studied varieties significantly affected nitrogen $\%, \mathrm{~N}$ uptake plant $^{-1}$ and $\mathrm{N}$ uptake fed ${ }^{-1}$ traits in both seasons except $\mathrm{N} \%$ trait in the $1^{\text {st }}$ season. G.99-103 variety recorded the highest values of $\mathrm{N}$ uptake plant ${ }^{-1}$ and $\mathrm{N}$ uptake fed ${ }^{-1}$ followed by G.T.54-9 variety while the lowest values of these traits were obtained by G.47-2003 variety.

\subsection{Bio and inorganic fertilizer effect:}

Results in Table (7) showed that application of Bio and inorganic fertilizer of nitrogen increased gradually in values of these traits until the 3 treatment $(75 \% \mathrm{~N}+$ bio fertilizer) then decreased the values of these trails in both seasons. Results recorded the lowest values of these traits when using $50 \% \mathrm{~N}+$ bio fertilizer in both seasons. These results may be attributed that nitrogen element has a role in enhancing the vegetative growth of plants and reflecting in yield in the final where it was increases by increasing $\mathrm{N}$ mixed bio fertilizer until $75 \% \mathrm{~N}$ mixed bio fertilizer level, only. These are in agreement with that obtained by (Kravchenko et al., 2002) Biochemical analysis of chlorophyll, nitrogen, phosphorous, potassium and protein content was higher in Azotobacter inoculated plants as compared to un inoculated control plants. 


\subsection{Interactions effects:}

The interaction between varieties and treatments of nitrogen fertilizer alone or mixed by bio fertilizer significantly affected the previous traits in both seasons. It was noticed from the table that under any variety of sugarcane, treatment $75 \% \mathrm{~N}$ mixed with bio fertilizer recorded the maximum value of the previous traits followed by $100 \% \mathrm{~N}+$ bio fertilizer and $50 \% \mathrm{~N}+$ bio fertilizer. Generally, G99103 variety surpassed the highest value for these traits when fertilizer by $75 \% \mathrm{~N}+$ bio fertilizer in both seasons which recorded $(2.64,2.69 \%) \mathrm{N} \%,(0.04,0.04 \%) \mathrm{N}$ uptake plant ${ }^{-1}$ and $(166.8,171.8 \%) \mathrm{N}$ uptake $\mathrm{fed}^{-1}$ in the $1^{\text {st }}$ and $2^{\text {nd }}$ season, respectively. These findings are in agreement with that obtained by (Berger et al., 2013) $\mathrm{N}$ is one of the most important nutrients to increase plant growth and yield, due to its role in chemical compounds such as proteins, nucleic acids and many other components, it is necessary for all kinds of life throughout the world.

Table 7: Effect of bio and inorganic fertilizer on $\mathrm{N} \%, \mathrm{~N}$ uptake plant ${ }^{-1}$ and $\mathrm{N}$ uptake fed ${ }^{-1}$ of some sugarcane varieties and their interactions in 2016/2017 and 2017/2018 seasons

\begin{tabular}{|c|c|c|c|c|c|c|c|c|}
\hline \multirow{4}{*}{ Bio and inorganic fertilizer } & \multicolumn{8}{|c|}{ Nitrogen \% } \\
\hline & \multicolumn{4}{|c|}{ First season } & \multicolumn{4}{|c|}{ Second season } \\
\hline & \multicolumn{8}{|c|}{ Varieties } \\
\hline & $\begin{array}{c}\text { G.T.54- } \\
9\end{array}$ & $\begin{array}{l}\text { G.47- } \\
2003\end{array}$ & $\begin{array}{c}\text { G99- } \\
103\end{array}$ & Mean & $\begin{array}{c}\text { G.T.54- } \\
9 \\
\end{array}$ & $\begin{array}{l}\text { G.47- } \\
2003\end{array}$ & $\begin{array}{c}\text { G99- } \\
103 \\
\end{array}$ & Mean \\
\hline $100 \%$ N RD & 2.24 & 2.22 & 2.21 & 2.34 & 2.29 & 2.27 & 2.26 & 2.39 \\
\hline $50 \%$ N RD+ A. chroococcum & 2.35 & 2.36 & 2.32 & 2.23 & 2.40 & 2.41 & 2.37 & 2.28 \\
\hline $75 \%$ N RD+A. chroococcum & 2.45 & 2.34 & 2.64 & 2.45 & 2.50 & 2.39 & 2.69 & 2.50 \\
\hline $100 \%$ N RD + A. chroococcum & 2.33 & 2.36 & 2.37 & 2.35 & 2.38 & 2.41 & 2.42 & 2.40 \\
\hline Mean & 2.34 & 2.33 & 2.35 & 2.34 & 2.39 & 2.38 & 2.40 & 2.39 \\
\hline LSD $_{0.05}$ & \multicolumn{4}{|c|}{ NS } & \multicolumn{4}{|c|}{0.02} \\
\hline LSD 0.05 & \multicolumn{4}{|c|}{0.03} & \multicolumn{4}{|c|}{0.06} \\
\hline LSD $_{0.05}$ & \multicolumn{4}{|c|}{0.05} & \multicolumn{4}{|c|}{0.08} \\
\hline \multicolumn{9}{|c|}{ Uptake plant $^{-1}$} \\
\hline $100 \%$ N RD & 0.026 & 0.022 & 0.031 & 0.026 & 0.031 & 0.027 & 0.036 & 0.031 \\
\hline $50 \%$ N RD + A. chroococcum & 0.022 & 0.021 & 0.028 & 0.024 & 0.027 & 0.026 & 0.033 & 0.029 \\
\hline $75 \%$ N RD + A. chroococcum & 0.028 & 0.026 & 0.036 & 0.030 & 0.033 & 0.032 & 0.041 & 0.035 \\
\hline $100 \% \mathrm{~N} \mathrm{RD}+$ A. chroococcum & 0.027 & 0.025 & 0.035 & 0.029 & 0.032 & 0.030 & 0.040 & 0.034 \\
\hline Mean & 0.026 & 0.023 & 0.033 & 0.027 & 0.031 & 0.028 & 0.038 & 0.031 \\
\hline LSD $_{0.05}$ & \multicolumn{4}{|c|}{0.002} & \multicolumn{4}{|c|}{0.005} \\
\hline LSD $_{0.05}$ & \multicolumn{4}{|c|}{0.001} & \multicolumn{4}{|c|}{0.003} \\
\hline LSD $_{0.05}$ & \multicolumn{4}{|c|}{0.002} & \multicolumn{4}{|c|}{0.003} \\
\hline \multicolumn{9}{|c|}{ Uptake fed $^{-1}$} \\
\hline $100 \%$ N RD & 127.47 & 103.73 & 137.12 & 122.79 & 132.41 & 108.71 & 142.11 & 127.71 \\
\hline $50 \%$ N RD+A. chroococcum & 113.74 & 98.85 & 124.10 & 112.23 & 118.72 & 103.81 & 129.12 & 117.21 \\
\hline $75 \%$ N RD+A. chroococcum & 140.38 & 124.15 & 166.84 & 143.79 & 145.32 & 129.12 & 171.81 & 148.72 \\
\hline $100 \%$ N RD + A. chroococcum & 128.13 & 117.01 & 151.67 & 132.27 & 133.12 & 122.03 & 156.65 & 137.27 \\
\hline Mean & 127.43 & 110.95 & 144.93 & 127.77 & 131.41 & 115.95 & 149.91 & 132.42 \\
\hline LSD $_{0.05}$ & \multicolumn{4}{|c|}{8.04} & \multicolumn{4}{|c|}{8.09} \\
\hline LSD $_{0.05}$ & \multicolumn{4}{|c|}{6.40} & \multicolumn{4}{|c|}{6.45} \\
\hline LSD 0.05 & \multicolumn{4}{|c|}{6.55} & \multicolumn{4}{|c|}{6.88} \\
\hline
\end{tabular}

\section{Cane yield ton fed ${ }^{-1}$, Sugar recovery and sugar yield ton fed $^{-1}$ traits:}

4.1. Varietal effect:

Results in Table (8) illustrated that varieties of sugarcane differed significantly in cane yield (ton $\left.\mathrm{fed}^{-1}\right)$, sugar recovery $(\%)$ and sugar yield $\left(\right.$ ton $\left.\mathrm{fed}^{-1}\right)$ traits. The data present indicated that significant increasing of the three varieties by cane yield ton fed ${ }^{-1}$, sugar recovery and sugar yield ton fed ${ }^{-1}$ traits. 
It could be demonstrated from the results that variety G.99-103 recorded the highest values of cane yield (64.18 and 65.34 ton) and sugar yield (6.18 and 16.84 ton), while variety G.T.54-9 recorded the highest values of sugar recovery (11.64 and $11.64 \%$ ), respectively treatment.

\subsection{Bio and inorganic fertilizer Effect:}

Results by Table (8) the effect bio and inorganic fertilizer of nitrogen. Results had recorded positive influence inoculation with Azotobacter chroccocum on cane yield ton fed ${ }^{-1}$, sugar recovery and sugar yield ton $\mathrm{fed}^{-1}$. The higher values had of $75 \% \mathrm{~N} \mathrm{RD}+$ bio fertilizer. (57.29 and 58.43 ton ) cane yield ton $\mathrm{fed}^{-1}$, (10.99 and $\left.11.09 \%\right)$ sugar recovery and (6.42 and 6.39 ton ) sugar yield ton $\mathrm{fed}^{-1}$, respectively, these results were agreed with Shaban and Helmy (2006) who stated that nitrogen uptake was increased significantly by the application of different nitrogen rates and Azotobacter as compared to the control.

Table 8: Effect of bio and inorganic fertilizer on cane yield ton fed ${ }^{-1}$, sugar recovery and sugar yield ton $\mathrm{fed}^{-1}$ of some sugarcane varieties and their interactions in 2016/2017 and 2017/2018 seasons

\begin{tabular}{|c|c|c|c|c|c|c|c|c|}
\hline \multirow{4}{*}{ Bio and inorganic fertilizer } & \multicolumn{8}{|c|}{ Cane yield ton fed ${ }^{-1}$} \\
\hline & \multicolumn{4}{|c|}{ First season } & \multicolumn{4}{|c|}{ Second season } \\
\hline & \multicolumn{8}{|c|}{ Varieties } \\
\hline & $\begin{array}{c}\text { G.T.54- } \\
9 \\
\end{array}$ & $\begin{array}{l}\text { G.47- } \\
2003 \\
\end{array}$ & $\begin{array}{c}\text { G99- } \\
103 \\
\end{array}$ & Mean & $\begin{array}{c}\text { G.T.54- } \\
9\end{array}$ & $\begin{array}{l}\text { G.47- } \\
2003 \\
\end{array}$ & $\begin{array}{c}\text { G99- } \\
103 \\
\end{array}$ & Mean \\
\hline $100 \%$ N RD & 53.50 & 46.00 & 64.87 & 54.79 & 54.50 & 47.77 & 66.23 & 56.17 \\
\hline $50 \%$ N RD + A. chroococcum & 43.60 & 41.07 & 54.23 & 46.30 & 44.83 & 42.20 & 55.70 & 47.58 \\
\hline $75 \%$ N RD + A. chroococcum & 51.93 & 48.77 & 69.13 & 57.29 & 53.03 & 50.30 & 69.87 & 58.43 \\
\hline $100 \%$ N RD + A. chroococcum & 53.60 & 49.80 & 68.47 & 56.61 & 55.07 & 50.67 & 69.57 & 57.73 \\
\hline Mean & 50.66 & 46.30 & 64.18 & 53.75 & 51.89 & 47.73 & 65.34 & 54.98 \\
\hline LSD $_{0.05}$ & \multicolumn{4}{|c|}{1.31} & \multicolumn{4}{|c|}{1.42} \\
\hline LSD $_{0.05}$ & \multirow{2}{*}{\multicolumn{4}{|c|}{$\begin{array}{c}3.45 \\
\text { NS }\end{array}$}} & \multirow{2}{*}{\multicolumn{4}{|c|}{$\begin{array}{l}3.57 \\
N S\end{array}$}} \\
\hline LSD 0.05 & & & & & & & & \\
\hline \multicolumn{9}{|c|}{ Sugar recovery \% } \\
\hline $100 \%$ N RD & 11.61 & 10.24 & 10.61 & 10.82 & 11.73 & 10.31 & 10.68 & 10.91 \\
\hline $50 \%$ N RD + A. chroococcum & 12.01 & 10.29 & 10.63 & 10.98 & 12.11 & 10.35 & 10.70 & 11.05 \\
\hline $75 \%$ N RD + A. chroococcum & 11.94 & 10.38 & 10.66 & 10.99 & 12.07 & 10.46 & 10.72 & 11.09 \\
\hline $100 \% \mathrm{~N} \mathrm{RD}+$ A. chroococcum & 11.02 & 10.68 & 9.76 & 10.49 & 11.20 & 10.72 & 9.81 & 10.57 \\
\hline Mean & 11.64 & 10.40 & 10.42 & 10.82 & 11.78 & 10.46 & 10.48 & 10.91 \\
\hline LSD $_{0.05}$ & \multicolumn{4}{|c|}{0.31} & \multicolumn{4}{|c|}{0.32} \\
\hline LSD $_{0.05}$ & \multicolumn{4}{|c|}{0.19} & \multicolumn{4}{|c|}{0.22} \\
\hline LSD 0.05 & \multicolumn{4}{|c|}{0.50} & \multicolumn{4}{|c|}{0.52} \\
\hline \multicolumn{9}{|c|}{ Sugar yield ton fed ${ }^{-1}$} \\
\hline $100 \%$ N RD & 6.18 & 4.86 & 7.01 & 6.01 & 6.40 & 4.93 & 7.10 & 6.13 \\
\hline $50 \% \mathrm{~N}$ RD + A. chroococcum & 5.31 & 4.30 & 5.91 & 5.17 & 5.43 & 4.37 & 5.96 & 5.25 \\
\hline $75 \%$ N RD + A. chroococcum & 6.30 & 5.23 & 7.73 & 6.42 & 6.40 & 5.27 & 7.49 & 6.39 \\
\hline $100 \% \mathrm{~N}$ RD + A. chroococcum & 6.04 & 5.35 & 7.34 & 6.24 & 6.16 & 5.41 & 6.82 & 6.13 \\
\hline Mean & 5.96 & 4.93 & 7.02 & 5.97 & 6.10 & 4.99 & 6.84 & 5.98 \\
\hline LSD $_{0.05}$ & \multicolumn{4}{|c|}{0.66} & \multicolumn{4}{|c|}{0.42} \\
\hline LSD 0.05 & \multirow{2}{*}{\multicolumn{4}{|c|}{$\begin{array}{c}0.71 \\
\text { NS }\end{array}$}} & \multirow{2}{*}{\multicolumn{4}{|c|}{0.55}} \\
\hline LSD $_{0.05}$ & & & & & & \multicolumn{3}{|c|}{ NS } \\
\hline
\end{tabular}

\subsection{Interactions effect:}

Interactions between of varieties and Bio and inorganic fertilizer by regard to cane yield ton fed ${ }^{1}, \mathrm{SR} \%$ and sugar yield ton $\mathrm{fed}^{-1}$ are scored in Table (8). Interaction between the varieties and levels of nitrogen fertilizer mixed with bio fertilizer by maximum increase significant difference observed in var. G99- 103 with (75\% N RD + A. chroococcum.) by SR. While increase was un- significant with yield ton fed ${ }^{-1}$, and yield of sugar ton $\mathrm{fed}^{-1}$ in the $1^{\text {st }}$ season. Sugar cane variety G.99-103 attained the highest sugar yield in the two growing seasons. The increase in cane yield may be attributed to increasing quality traits as a result in fertilizing plants by nitrogen and bio fertilizer which improving and building plant organic through synthesis of protein and its integral part of the chlorophll molecules. Also, 
nitrogen important to the synthesis of sucrose and the reactions involving the utilization of sucrose as an energy source for plant growth and cell maintenance. So, the final product (sugar yield) became higher with helping the gene make up of varieties of sugarcane. Varietal influence on sugar yield had been recorded by Ibraheem Abd Elateef et al., (2016).

\section{References}

Ahmed, A.Z., 2017. Response of three sugar cane varieties to phosphorus bio fertilization. Egypt J. Agron., 42(2):149-158.

A.O.A.C., 1995. Association of Official Analytical Chemists. Official methods of analysis, $16^{\text {th }}$ Ed. A.O.A.C International Washington, D.C., USA.

Abdel-Malek, Y. and Y.Z. Ishac, 1968. Evaluation of methods used in counting Azotobacter. J. Appl. Bact. 31:269-275.

Abu-Ellail, F.F.B., A.F.I. Gadallah and I.S.H. El-Gamal, 2020. Genetic Variance and Performance of Five Sugarcane Varieties for Physiological, Yield and Quality Traits Influenced by Various Harvest Age. J. of Plant Production, Mansoura Univ., 11 (5):429 - 4380.

Abu-Ellail, F.F.B., M.I. Masri and A.B.A. El-Taib, 2018. Performance of some new sugarcane clones for yield and its components at two different crop cycles. Indian J. Sugarcane Technol. 33(01): 2734.

Ali, S.E., R.A. El Gedaily, A. Mocan, M.A. Farag, and H.R. El-Seedi, 2019. Profiling metabolites and biological activities of sugarcane (Saccharum officinarum Linn.) juice and its product molasses via a multiplex metabolomics approach. Molecules, 24 (5): 934.

Allen, O.N., 1959. Experiments in soil Bacteriology. Burgess publishing Co., Minneapolis, Minnesota, USA.

Ambesh A. Roy, S. Ngomle, P.M. Bhattachary and V.S. Meena, 2017. Isolation and Evaluation of Azotobacter spp. from Different Crop Rhizosphere International Journal of Current Microbiology and Applied Sciences, 6 (4): 883-888.

Araujo, J., B. Urbano and F. González-Andrés, 2020. Comparative environmental life cycle and agronomic performance assessments of nitrogen fixing rhizobia and mineral nitrogen fertilizer applications for pulses in the Caribbean region. Journal of Cleaner Production, 267, 122065.

Berger, L.R.R., N.P. Stamford, C.E.R.S. Santos, Freitas, A.D.S., Franco, L.O., Stamford, T.C.M. 2013. Plant and soil characteristics affected by biofertilizers from rocks and organic matter inoculated with diazotrophic bacteria and fungi that produce chitosan. J. Soil Sci. Plant Nutr., 13, 592-603.

Chandrasekar, B.R., G. Ambrose, and N. Jayabalan, 2005. Influence of bio fertilizers and nitrogen source level on the growth and yield of Echinochloa frumentacea (Roxb.) Link. Journal of Agriculture Technology 1(2): 223-234.

Cochran, W.G., 1950. Estimation of bacterial densities by means of the "Most Probable Number". Biometrics. (6). 105-116.

Dada, O.A., C.E.R.S. Kutu, O.O. Babalola and A.O. Togun, 2020. Promoting bio fertilizer utilization for sustainable crop production: Produce quality and human health implications. Strategies and Tactics of Sustainable Agriculture in the tropics. (pp.37-60).

Das, I., and O. O. Pradhan, 2016. Potassium-solubilizing microorganisms and their role in enhancing soil fertility and health. In Potassium solubilizing microorganisms for sustainable agriculture (pp. 281 - 291). Springer, New Delhi.

Elias, S.M. and R. Karim, 1984. Application of partial budget technique in cropping system research at Chittagong. AEER No. 10 April, Econ. Div., BARI, Gazipur, Bangladesh, pp: 75-81.

EL-Shafai, A.M.A. and A.M.A. Ismail, 2006. Effect of row spacing on yield and quality of some promising sugar cane varieties. Egypt. J. Appl. Sci., 21 (11):32-46.

Essaam, M.A. Yassin and M.K. Enas Kassem, 2020. Occurrence of Different Acari Associated with Sugarbeet and Sugarcane In Kafr El-Sheikh and Qena Governortes, Egypt. Egypt. Acad. J. Biolog. Sci., 13 (3):119-126.

Gomez, K.A. and A.A. Gomez, 1984. Statisticalprocedures for agricultural research. 2nd ed.Wiley, New York. p. 680 
Hari, K., and T.R. Srinivasan, 2005. Response of sugarcane varieties to application of nitrogen fixing bacteria under different nitrogen levels. Sugar Tech 7(2\&3): 28-31.

Hoskine, J. K., 1934. The most probable numbers for evaluation of coliaerogenes test by fermentation tube method. Cited by porter, J. R. In: Bacterial chemistry and physiology, 2nd ed, New York, London, John Wiley@ Sons, p.100.

Ibraheem, A. Abd Elateef, Mohamed S. Abbas, El-Sayed I. Gaber, Laila M.A Saif and Ibrahim H ElGeddawy, 2016. Quality and Yield Traits of Three Sugar Cane Varieties as Affected by Different Levels of Nitrogen and Potassium Fertilizations in Egypt. Research Journal of Pharmaceutical, Biological and Chemical Sciences, P. 1253-1263.

Ishwaq Peerzada, A., K. Vijai Mohd and F. Malik, 2009: Effect of Bio-Organic Fertilizer on the Performance of Cabbage under Western U.P. Conditions, Annals of Horticulture, 2(2):204-206.

Jackson, M. L., 1967. Soil Chemical Analysis. Prentice Hall, Inc., Englewood Cliffs, NJ., USA.

Kader, M.A., M.H. Mian, and M.S. Hoque, 2002. Effects of Azotobacter inoculant on the yield and nitrogen uptake by wheat. Online Journal of Biological Sciences 2(4): 259-261.

Kravchenko, L.V., N.M. Makarova, T.S. Azarova, N.A. Provorov, and I. A. Tikhonovich, 2002. Isolation and phenotypic characterization of plant growth-promoting rhizobacteria with high antiphytopathogenic activity and root-colonizing ability. Microbiology, 71(4), 444-448.

Nemeat Alla, H.E. A., D.I. El-Geddawyand B.S.I. Makhlouf, 2015. Effect of Yeast Application Method and Number on Yield and Quality of Sugar Beet under Different Levels of Nitrogen. Journal of Plant Production, 6 (9): 1475-1490.

Patil, S.V., B.V. Mohite, C.D. Patil, S.H. Koli, H.P. Borase and V.S. Patil, 2020. Azotobacter. In Beneficial Microbes in Agro-Ecology (pp. 397-426). Academic Press..

Postage, J.R., 1972. The acetylene reduction test for nitrogen fixation. Meth. Microbiol., 66: 343.

Raimam, M.P., U. Albino, M.F. Cruz, G.M. Lovato, F. Spago, T.P. Ferracin, Lima, D.S., Goulart, M.A. and $\mathrm{G}$. Andrade, 2007. Interaction among free-living $\mathrm{N}$-fixing bacteria isolated from Drosera villosa var. villosa and AM fungi (Glomus clarm) in rice (Oryza sativa), Appl. Soil Ecol., 35 (1):25 -34 .

Satisha, G.C., M. Krishnappa and K. Srikanth, 1996. Input of sulphur on yield and quality of sugarcane. Indian Sugar 45(9): 397-401.

Satwant K.G., K. Anu, K.U. Satinder, K. Rajinder, S.W. Sohan, S. Kuldeep and S. Harpal, 2012. Assessing the Benefits of Azotobacter Bacterization in Sugarcane. Sugar Tech 14(1):61-67.

Serna-cock, Liliana, C. ARIAS-GARCÍA, L.J.V. Hernandez, 2011. Effect of bio fertilization on the growth of potted sugarcane plants (Saccharum officinarum). Biotecnología en el Sector Agropecuario y Agroindustrial, 9 (2), 85-95.

Shaban, K.A. and A. M. Helmy, 2006. Response of wheat to mineral and Bio N-fertilization under saline conditions. Zagazig J. Agric. Res, 33(6): 1189-1205.

Shankaraiah, C., and K.N. Kalyana Murthy, 2005: Effect of enriched pressmud cake on growth, yield and quality of sugarcane." Sugar Tech 7.2: 1-4.

Somasegaran, P., and H.J. Hoben, 1994. Quantifying the growth of rhizobia. In Handbook for rhizobia (pp. 47-57). Springer, New York, NY.

Wani, S.A., S. Chand, M.A. Wani, M. Ramzan, and K.R. Hakeem, 2016. Azotobacter chroococcum-a potential bio fertilizer in agriculture: an overview. Soil science: agricultural and environmental prospectives, 333-348.

Wu, S.C., Z.H. Cao, Z.G. Li, K.C. Cheung and M.H. Wong, 2005. Effects of biofertilizer containing $\mathrm{N}$-fixer, $\mathrm{P}$ and $\mathrm{K}$ solubilizers and AM fungi on maize growth: a greenhouse trial, Geoderma, 125 (1-2): 155- 166. Effects of biofertizer containing N- fixer, P and $\mathrm{K}$ soluilizers and AM fungi on maize growth: agreenhouse trial, Geoderma, 125 (1-2), p. 155- 166.

Yadav, R.L. and R.K. Sharma, 1980. Effect of N level and harvesting date on quality characteristics and yield of sugarcane genotypes. India J. Agric. Sci., 50: 581-589.

Yaser M.A., E.M. Taha, Sh.A. Mokadem and K.S. El-Sogheir, 2008. Evaluation of some new sugarcane varieties as affected by harvesting dates under middle and upper Egypt conditions. M.S.C., 5-108. 
Youssef, A.S.M. (2020): Response of caraway (Carum carvi L.) plant to bio-fertilizers in substitution of chemical fertilization. Journal of Medicinal Plants, 8 (6): 45-54.

Yousif, E.M.M., M.M. Ibrahim, A.O.K. El- Aref and A.Z. Ahmed, 2015. Management of nitrogen fertilization for sugar cane on a sandy soil: 1 yield and its components. Egypt. J. Appl. Sci.30 (11):498-511.

Zaki, A., 2017. Response of three Sugar Cane Varieties to Phosphorus Bio Fertilization. Egy. J. Agron., 39 (2):149-158. 